\title{
The whole - genome expression analysis of peripheral blood mononuclear cells from aspirin sensitive asthmatics versus aspirin tolerant patients and healthy donors after in vitro aspirin challenge
}

Joanna Wieczfinska', Dorota Kacprzak¹, Karolina Pospiech², Milena Sokolowska ${ }^{1,3}$, Magdalena Nowakowska², Ewa Pniewska ${ }^{1}$, Andrzej Bednarek², Izabela Kuprys-Lipinska ${ }^{4}$, Piotr Kuna ${ }^{4}$ and Rafal Pawliczak ${ }^{1 *}$

\begin{abstract}
Background: Up to $30 \%$ of adults with severe asthma are hypersensitive to aspirin and no unambiguous theory exists which provides a satisfactory explanation for the occurrence of aspirin-induced asthma (AIA) in some asthmatic patients. Therefore, the aim of this study was to compare the AIA expression profile against aspirin tolerant asthma (ATA) and healthy volunteers (HV) profile in peripheral blood mononuclear cells (PBMCs) after in vitro aspirin challenge in Caucasian population.

Methods: PBMCs were separated from blood of three groups of subjects - 11 AIA, 7 ATA and 15 HV and then stimulated by either $2 \mu \mathrm{M}$ lysine aspirin or $20 \mu \mathrm{M}$ lysine as a control. Subsequently, RNA was isolated, transcribed into CDNA and subjected to microarray and GPCR studies. Simultaneously, protein was extracted from PBMCs and used in further immunoblotting analysis.

Results: The validation of results at mRNA level has shown only three genes, whose expression was significantly altered between comprising groups. mRNA expression of CNPY3 in PBMCs in AIA was significantly lower $(-0.41 \pm 2.67)$ than in HV (1.04 \pm 2.69$)$, $(p=0.02)$; mRNA expression of FOSL1 in PBMCs in AIA was also significantly decreased $(-0.66 \pm 2.97)$ as opposed to HV $(0.31 \pm 4.83)$, $(p=0.02)$. While mRNA expression of ERAS in PBMCs was increased $(1.15 \pm 0.23)$ in AIA in comparison to HV $(-1.32 \pm 0.41),(p=0.03)$. At protein level the changed expression of one protein was confirmed. Protein expression of FOSL1 in PBMCs in AIA was both significantly lower $(-0.86 \pm 0.08)$ than in ATA $(0.39 \pm 0.42),(p=0.046)$ and in HV $(0.9 \pm 0.27),(p=0.007)$.
\end{abstract}

Conclusions: This pilot study implies a positive association between CNPY3, ERAS, FOSL1 and aspirin-intolerant asthma, suggesting that these findings would be useful for further investigations of NSAIDs mechanism.

Keywords: Aspirin - induced asthma, Aspirin, Nonsteroidal anti-inflammatory drugs, Asthma

\footnotetext{
*Correspondence: rafal.pawliczak@umed.lodz.pl

'Department of Immunopathology, Medical University of Lodz, Chair of

Allergology, Immunology and Dermatology, 7/9 Zeligowskiego, 90-752 Lodz,

Poland

Full list of author information is available at the end of the article
}

\section{Biomed Central}

(c) 2015 Wieczfinska et al. Open Access This article is distributed under the terms of the Creative Commons Attribution 4.0 International License (http://creativecommons.org/licenses/by/4.0/), which permits unrestricted use, distribution, and reproduction in any medium, provided you give appropriate credit to the original author(s) and the source, provide a link to the Creative Commons license, and indicate if changes were made. The Creative Commons Public Domain Dedication waiver (http://creativecommons.org/publicdomain/zero/1.0/) applies to the data made available in this article, unless otherwise stated. 


\section{Background}

Aspirin-exacerbated respiratory disease (AERD) is a distinct asthma phenotype mainly characterized by chronic eosinophilic inflammation of the upper and lower airways with symptoms that are exacerbated by aspirin and other nonsteroidal anti-inflammatory drugs (NSAIDs) [1-4].

It is estimated that $0.6-2.5 \%$ of total population $[5,6]$, $5-10 \%$ of asthmatic adults [7-9], almost $30 \%$ adults with severe asthma [10] and just about $40 \%$ of asthmatic adults with refractory chronic hyperplastic sinusitis [11] are hypersensitive to aspirin (ASA). Emphatically, more than $15 \%$ of asthmatic patients are quite unaware of suffering from this intolerance [12] and only provocation tests may reveal AIA. Higher incidence of AIA was also reported in women in whom symptoms start earlier and disease course is more rapid and severe [13].

Although the exact pathomechanism of AIA still remains unknown, pathognomonic reactions to $\mathrm{COX}-1$ active drugs can be attenuated by inhibitors of 5-lipoxygenase (5-LOX), type 1 receptor for cysteinyl leukotriens (cysLTR1) [14] and by drugs that block mast cells (MA) activation $[15,16]$. Moreover, inhaled prostaglandin $\mathrm{E}_{2}\left(\mathrm{PGE}_{2}\right)$ inhibits aspirin - induced bronchoconstriction and cysLT production in subjects with AERD [17]. $\mathrm{PGE}_{2}$ is formed from COX-dependent conversion of arachidonic acid to $\mathrm{PGH}_{2}$, which is metabolized to $\mathrm{PGE}_{2}$ by three $\mathrm{PGE}_{2}$ synthases (PGESs) [18]: cytosolic PGES and microsomal PGES (mPGES-1 and mPGES-2) [19, 20]. Absence of mPGES-1 impairs the up-regulation of $\mathrm{PGE}_{2}$ production in mice [21]. Additionally $\mathrm{PGES}^{-/}$mice develop marked eosinophil - dominated bronchovascular cellular infiltrates with lesser numbers of neutrophiles $[22,23]$ and lysine aspirin (Lys-ASA) challenge caused additively releases of two markers of MC activation histamine, mMCP-1 and cysLTs [21]. The marked depletion of residual $\mathrm{PGE}_{2}$ by Lys-ASA in the $\mathrm{PGES}^{-/-}$ mice suggests that $\mathrm{mPGES}-1$ sustains $\mathrm{PGE}_{2}$ generation in the face of COX-1 inhibition [21]. It has been also demonstrated that platelet- adherent eosinophils and neutrophils are more frequent in the peripheral blood and sinonasal tissues from patients with AERD than in samples from aspirin tolerant controls [24]. Adherence to platelets primes granulocyte integrin function [25], chemotaxis [26] and increase susceptibility to inflammation [21]. It is probably that TP receptors are essential for platelet-adherent granulocytes to generate cysLTs by facilitating cross - talk between platelets and granulocytes [21]. Though the residual local $\mathrm{PGE}_{2}$ derives principally from $\mathrm{COX}-1$, which may explain why only COX-1 - active drugs provoke clinical reactions [27].

It is also known that the production of 15-hydroxyeicosatetranoic acid (15-HETE) in AIA patients is 3.6 fold higher than in ATA patients [28]. The substantial source of 15-HETE in this reaction seems to be 15-lipooxygenase (15-LOX) that is controlled by COX-1 [29]. Thus, inhibition of COX-1 and disregulation of $\mathrm{PGE}_{2}$ production by aspirin results in activation of 15 LOX and 15-HETE production [28]. Overproduction of 15-HETE in aspirin sensitive asthmatics inter alia contributes to the induction of mucous glycoprotein secretion by human airway [30] and contraction of bronchial smooth muscles [31]. According to these results in - vitro test (ASPItest) is known that measures ASA - induced 15 HETE in peripheral blood. ASPItest does not require special expertise, equipment and seems to be highly sensitive and specific to confirm the history of aspirin sensitivity in asthmatic patients [29].

So far, in the literature there is also a lot of data concerning genetic mechanisms suggesting the involvement of various candidate genes in the pathogenesis of AIA. Unfortunately, the majority of these results is not consistent between various populations indicating environmental factors which may predestine to development of AIA. Moreover, the likelihood that AIA is acquired in adulthood implies potential epigenetic modifications of the relevant mediator systems. Hence, it has been demonstrated that $\mathrm{PGE}_{2}$ synthase gene in nasal polyps from subjects with AERD is hypermethylated in comparison to nasal polyps from aspirin - tolerant controls [32].

The aim of this study was to explore the possible difference between aspirin-induced asthma (AIA), aspirin tolerant asthma (ATA) and HV (healthy volunteers) genetic profiles in PBMCs in Caucasian population by means of whole genome scan after in vitro aspirin challenge.

\section{Methods}

\section{Study subjects}

Subjects of Caucasian origin were recruited from Department of Internal Medicine, Asthma and Allergy; Medical University of Lodz; Poland. The diagnosis of bronchial asthma was based on an patient's history, physical examination and pulmonary function tests according to Global Initiative for Asthma (GINA) 2014 guidelines. Asthmatic patients were included in the study if they met the following criteria: clinical diagnosis of asthma confirmed by bronchial hyperactivity assessed by a positive bronchodilator or methacholine test, the incidence of asthmatic attacks and no other respiratory disorders. Patients were asked to refrain from short acting bronchodilators for at least six hours before challenge.

Aspirin-sensitive asthmatic subjects were included in the study if they had a positive oral provocation test with aspirin during the last 6 months, made without the context of the study. Patients with aspirin-tolerant asthma and healthy subjects were involved in the project if they had had a negative history of aspirin or other NSAIDs hypersensitivity and had been exposed to these medicaments during at least the last six months without any 
adverse events before the study. The clinical profiles of asthma patients and healthy control subjects are summarized in Table 1 . The study protocol was approved by the Ethics Committee of the Medical University of Lodz (permission no. RNN/107/08/KE, RNN/103/11/KE) and written consent was obtained from every subject prior to the study.

\section{PBMCs isolation and incubation with lysine aspirin/lysine}

Peripheral venous blood was collected before aspirin challenge. PBMCs were separated using Histopaque 1077 solution (Sigma Aldrich, Saint Louis, MO) according to the manufacturer's protocol, washed three times in PBS. Afterwards, the PBMCs were incubated either wuth lysine aspirin $(2 \mu \mathrm{M})$ or lysine $(20 \mu \mathrm{M})$ for $30 \mathrm{~min}$ at $37^{\circ} \mathrm{C}$. Incubation conditions for the cells were selected on the basis of previous, unpublished pilot studies. PBMC counts were not statistically different between groups before and after incubation with lysine aspirin or lysine.

\section{CDNA synthesis and microarray hybridization}

RNA was isolated (RNAeasy Mini Kit, Qiashredder (Qiagen, Hilden, Germany) and trascribed into cDNA (ImProm II Reverse Transcription Kit (Promega, Madison, Wisconsin)), which was subjected to microarray analysis.

\section{Microarray procedures}

Microarray flip dye experiments were performed with Human OneArray Whole Genome Microarrays v 5.1 (Phalanx Biotech, San Diego, CA) containing 30,255 oligonucleotide probes $(29,187$ human genome probes and 1,088 experimental control probes) was used for gene expression analysis. Each sample was hybridized against Universal Human Reference RNA (Stratagene, La Jolla, CA, USA) provided a common denominator for accurate and reproducible comparisons of gene expression data.
Single-stranded cDNA samples were labelled with Cy3 and Cy5 using ULS ${ }^{\mathrm{min}}$ Labelling Kit (Kreatech Diagnostics, Netherlands).

Synthesis of target cDNA probes and hybridization were performed according to protocol. The preparation of a slide for hybridization included pre-wash in ethanol and pre-hybridization according to manufacturer's protocol. Hybridization was performed in a humidity chamber filled with $2 \times$ SSPE buffer at $42{ }^{\circ} \mathrm{C}$ for $16-18$ h. Posthybridization washes were performed with the following buffers: $1 \times$ SSPE $/ 0.03 \%$ SDS $\left(2 \mathrm{~min}, 42{ }^{\circ} \mathrm{C}\right.$ ), $1 \times \mathrm{SSPE}$ ( 2 min, RT) and $0.1 \times$ SSPE (rinsed several times, RT).

\section{qPCR for candidate genes}

cDNA was subjected to qPCR using the kits of primers and probes designed for the selected genes and GAPDH as a qPCR reference (Life Technologies, Carlsbad, CA). Assay ID and contex sequences used in this study are shown in Table 2. Each sample was measured in duplicate using TaqMan analyzer 7900 (Life Technologies, Carlsbad, CA). Using the $2^{-\Delta \Delta C t}$ method, data are presented as a fold change in gene expression normalized to endogenous reference gene GAPDH and relative to a control (lysine-treated PBMCs). The fold change of mRNA expression in each patient was calculated by comparing RQ $\left(2^{-\Delta \Delta C t}\right)$.

\section{Protein isolation and immunoblotting analysis}

Total protein was isolated utilizing RIPA lysis buffer (Sigma, Saint Louis, MO) with addition of Protease Inhibitor Cocktail (Sigma, Saint Louis, MO) according to manufacturer's protocol and analyzed by immunoblotting method to detect selected proteins (Table 3) using $10 \mu \mathrm{g}$ total protein per sample. Detailed immunoblotting protocol is provided in Additional file 1.

Table 1 Characteristics of recruited aspirin - sensitive asthmatics, aspirin - tolerant asthmatics and healthy volunteers

\begin{tabular}{llll}
\hline & Aspirin - sensitive asthmatics & Aspirin - tolerant asthmatics & Healthy volunteers \\
\hline Number of subjects (n) & 11 & 7 & 15 \\
Gender ( $\mathrm{n}$, female/male) & $6 / 5$ & $3 / 4$ & $11 / 4$ \\
Age (years, median (range)) & $39(21-71)$ & $44(30-67)$ & $30(21-58)$ \\
FEV1 (\% predicted) & $81.45 \pm 19.36$ & $88.43 \pm 7.89$ & $84.64 \pm 20.47$ \\
PEF (\% predicted) & $89.14 \pm 20.24$ & $1120(400-2400)$ & $0(0-12)$ \\
Inhaled GCS ( $\mu$ g/day, mean (range)) & $1200(0-2400)$ & 14.3 \\
Systemic GCS (mg/day, mean (range) $)^{\text {b }}$ & 0 & 85.7 \\
Current smokers (\%) & 27.3 & 100 \\
Subjects with sinusitis (\%) & 63.6 & 85.7 \\
Subjects with rhinitis (\%) & 72.7 & 45.5 & Subjects with atopy (\%)
\end{tabular}

ainhaled GCS were calculated as budesonide equivalents, ${ }^{\mathrm{b}}$ systemic GCS were calculated as prednisone equivalents 
Table $\mathbf{2}$ qPCR probes used for expression analysis of specified genes

\begin{tabular}{|c|c|c|}
\hline Gene names & Context sequence ${ }^{*}\left(5^{\prime}\right.$ to $\left.3^{\prime}\right)$ & Catalog number \\
\hline ALOX5 & GGAGGTCCAGCAAGGGAAACA & Hs01095330_m1 \\
\hline ALOX15 & TATCTTCAAGCTTATAATTCC & Hs00609608_m1 \\
\hline BMP2 & CACCATGAAGAATCTITGGAA & Hs00154192_m1 \\
\hline CNPY3 & CCAAGGGCATGTCAGAGACCT & Hs00198139_m1 \\
\hline CSF1 & CATGACAAGGCCTGCGTCCGA & Hs00174164_m1 \\
\hline CXCL11 & ACAGTTGTTCAAGGCTTCCCC & Hs00171138_m1 \\
\hline DOCK9 & TTAAGTTGCTGCGAAACCAGA & Hs00324508_m1 \\
\hline DPP9 & CTACCTGGGAATGCCATATGG & Hs00373589_m1 \\
\hline ERAS & CGAGTGTTGTGTGGGTGGGAG & Hs00742161_s1 \\
\hline FOSL1 & CCCAGCAGAAGTTCCACCTGG & Hs04187685_m1 \\
\hline GAB3 & ACCTGGAAAGCTGATGTAGAA & Hs00369794_m1 \\
\hline MARVELD1 & GGGCCTGTAAGGTTTCCATGT & Hs00230362_m1 \\
\hline PARVG & AGCCTCCAAAGGACGTCTTTG & Hs00223323_m1 \\
\hline$R X R G$ & CAGATCCTCAGGAAAGCACTA & Hs00199455_m1 \\
\hline TLR7 & ACTAAAAATGGTGTTTCCAAT & Hs00152971_m1 \\
\hline TRIP6 & TGAGGACTTTCACAGGAAGTT & Hs00377979_m1 \\
\hline
\end{tabular}

*Assays ordered from Life Technologies are provided with context sequence surrounding the assay location. Probes contain typically $13-18$ bases and the minor groove binder (5-6 bases on 3 ' end stabilizing the probe)

\section{Statistical analysis \\ Microarray studies}

For microarray studies, detection of $p$ values and normalization were performed for the extracted values. Statistical significance of the microarray data was calculated by the Student's t test - standard two-sample $t$-statistics with pooled variance. Additional statistical analysis was performed using the false discovery rate (FDR) to correct for multiple comparisons in multiple hypothesis testing. FDR of a test was defined as the expected proportion of false positives among the declared significant results $[33,34]$ as it is a more convenient scale to work on instead of the p-value scale [35]; it is not too conservative for microarray studies and does not lead to low sensitivity [35].

For the diagnostic values of gene expression in the discrimination of AIA from ATA and healthy subjects, we selected candidate genes that satisfied the criteria of $p<0.05$ and exhibiting change in expression greater than twofold difference between the two chosen groups. For microarray analysis, backgroundcorrected values for each probe on oligonucleotide array were extracted using $\mathrm{MeV}$ software (TM4, Boston, MA).

\section{qPCR and immunoblotting analysis}

For $\mathrm{qPCR}$ and immunoblotting results, the distribution of the $\log _{2}$ data and the equality of variances were checked by Shapiro-Wilk and Levene's tests, respectively. The results were presented as mean \pm SEM when data in groups were normally distributed; differences between groups were examined for statistical significance by ANOVA with the appropriate post-hoc test. If Kruskal Wallis test (with multiple comparison) - non-parametric equivalent of ANOVA was used, the results were presented as median \pm range.

$P$ value $<0.05$ was considered as statistically significant. The data from the study was analyzed utilizing STATISTICA software package (Statsoft, Tulsa, OK).

Table 3 Primary antibodies used for immunoblotting

\begin{tabular}{|c|c|c|c|c|}
\hline Protein names & Primary antibody & Dilution & Producer & Catalog number \\
\hline ALOX5 & Rabbit polyclonal & $1: 1000$ & Cell Signalling & 3748 \\
\hline ALOX15 & Rabbit polyclonal & $1 \mathrm{mg} / \mathrm{ml}$ & Aviva Systems Biology & ARP56030_P050 \\
\hline BMP2 & Rabbit polyclonal & $1: 1000$ & Abnova & H00000650-D01P \\
\hline CNPY3 & Rabbit polyclonal & $0.2 \mu \mathrm{g} / \mathrm{ml}$ & Aviva Systems Biology & ARP34422_P050 \\
\hline CSF1 & Rabbit polyclonal & $1 / 100$ & Abcam & ab93335 \\
\hline CXCL11 & Rabbit polyclonal & $0.2 \mu \mathrm{g} / \mathrm{ml}$ & Abcam & ab9955 \\
\hline DOCK9 & Rabbit polyclonal & $1 / 5000$ & Abcam & ab70272 \\
\hline DPP9 & Rabbit polyclonal & $1 / 2500$ & Abcam & $a b 42080$ \\
\hline ERAS & Rabbit polyclonal & $0.2 \mu \mathrm{g} / \mathrm{ml}$ & Aviva Systems Biology & ARP55794_P050 \\
\hline FOSL1 & Rabbit monoclonal & $1: 1000$ & Cell Signalling & 5281 \\
\hline GAB3 & Rabbit polyclonal & $1 / 250$ & Abcam & ab121311 \\
\hline MARVELD1 & Rabbit polyclonal & $1 \mu \mathrm{g} / \mathrm{ml}$ & Abcam & ab91640 \\
\hline PARVG & Rabbit polyclonal & $1: 1000$ & Abnova & H00064098-D01P \\
\hline $\mathrm{RXRG}$ & Rabbit polyclonal & $1: 1000$ & Cell Signalling & 5629 \\
\hline TLR7 & Rabbit Polyclonal & $1: 5000$ & GeneTex & GTX125910 \\
\hline TRIP6 & Rabbit polyclonal & $0.2 \mu \mathrm{g} / \mathrm{ml}$ & Aviva Systems Biology & ARP51617_P050 \\
\hline
\end{tabular}




\section{Power analysis}

Sample size was calculated based on the number of aspirin sensitive patients counted per total population of Poland (6). Based on Daniel formula for calculating sample size (29), this gave a calculated AIA sample size approximately 9 patients. However, a higher number was targeted in qPCR in order to account for possible exclusions, dropouts and the need to carry out subgroup analysis.

\section{Results}

\section{Comparison of gene expression profiles between AIA} versus ATA and AIA versus healthy volunteers

The gene expression microarray consisting of 30.255 featured oligonucleotide probes to cDNA samples obtained from AIA $(n=5)$, ATA $(n=3)$ and healthy volunteers $(n=4)$ was applied. To evaluate the overall difference in gene expression levels in PBMCs among AIA, ATA and healthy volunteers, we calculated the gene expression level using a volcano plot (Figs. 1 and 2). Volcano plot against fold change values for each gene revealed that the expression levels were slightly different between AIA versus ATA and AIA versus healthy subjects. We identified genes that showed 325 significantly different expression between AIA vs. ATA (253 genes that showed a significant increase in gene expression and 72 genes that showed a significant decrease) and 376 genes with significantly changed expression between AIA versus healthy volunteers - 196 genes turned out to be significantly increased and 180 genes with statistically significant decreased expression (Figs. 3 and 4).

For the next step of analysis, we selected genes DPP9, RXRG and FOSL1 with a $p$ value of $<0.05$ and mean difference in fold change value $>2$ between the two chosen groups (Fig. 5). Differences in gene expression obtained in whole genome scan using cDNA microarrays was shown in Table 4 . The role of selected genes in inflammation or asthma had been confirmed in literature before. The upregulated and downregulated genes were perfectly classified by the hierarchical clustering method.

\section{Verification of gene expression with quantitative measurement of mRNA using qPCR}

We validated three previously selected genes: DPP9, RXRG and FOSL1 using qPCR to measure their mRNA levels in PBMCs obtained from AIA $(n=11)$, ATA $(n=7)$ and healthy volunteers $(n=15)$. Therefore qPCR was analyzed for original microarray patients' group and additional patients were added to have a confirmatory cohort.

Quantification of mRNA levels was performed by measuring the amount of DPP9, RXRG and FOSL1 qPCR product after correcting for amount of GAPDH. Additionally, qPCR analysis included validation of such genes as ALOX5, ALOX15, BMP2, CNPY3, CNPY3, CSF1, CXCL11, DOCK9, ERAS, GAB3, MARVELD1, PARVG, TLR7 and TRIP6 - markers of inflammation, formerly described in literature.

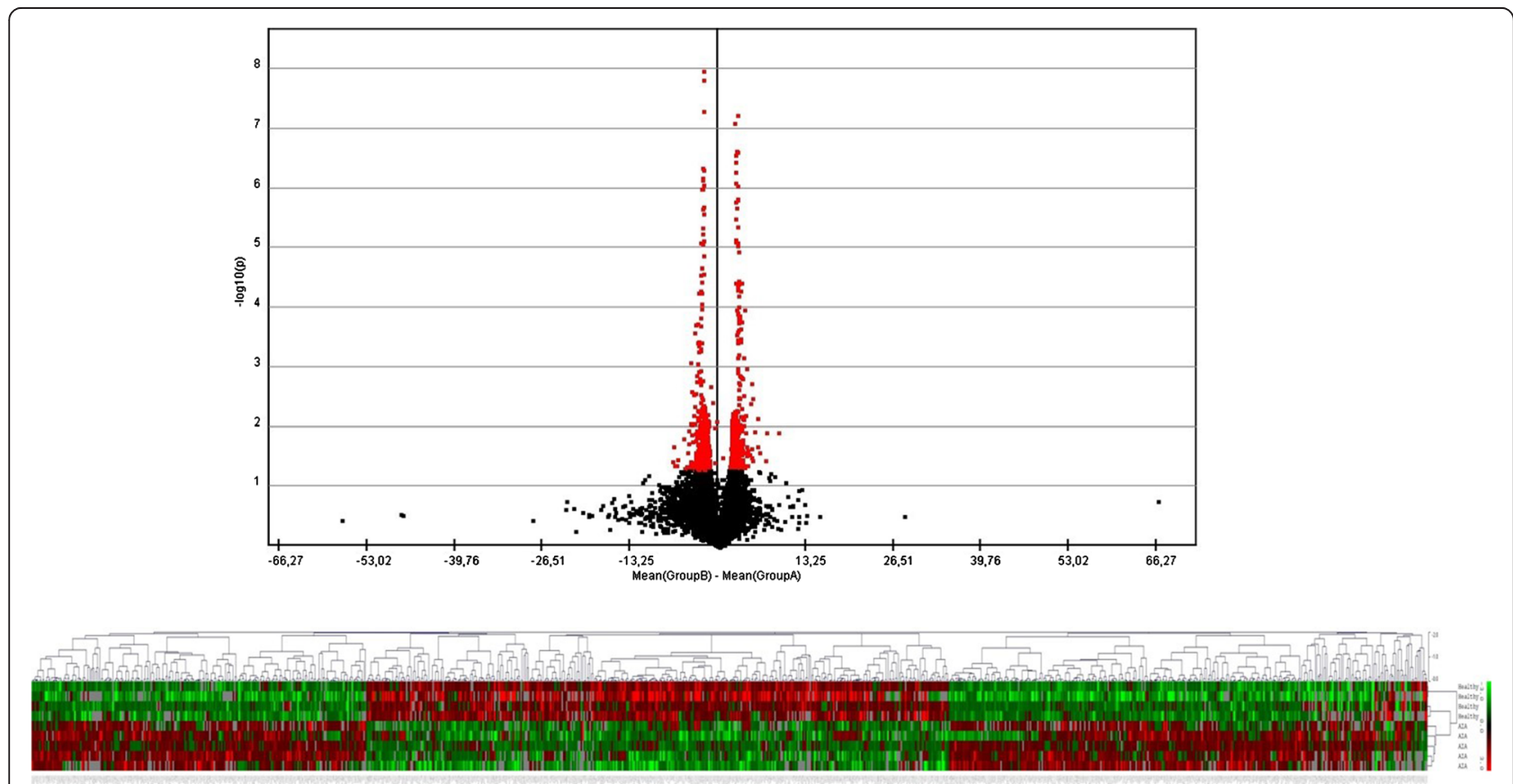

Fig. 1 Volcano plot and result of hierarchical clustering for $p<0.05$ obtained for aspirin-induced asthma and aspirin-tolerant asthma patients 


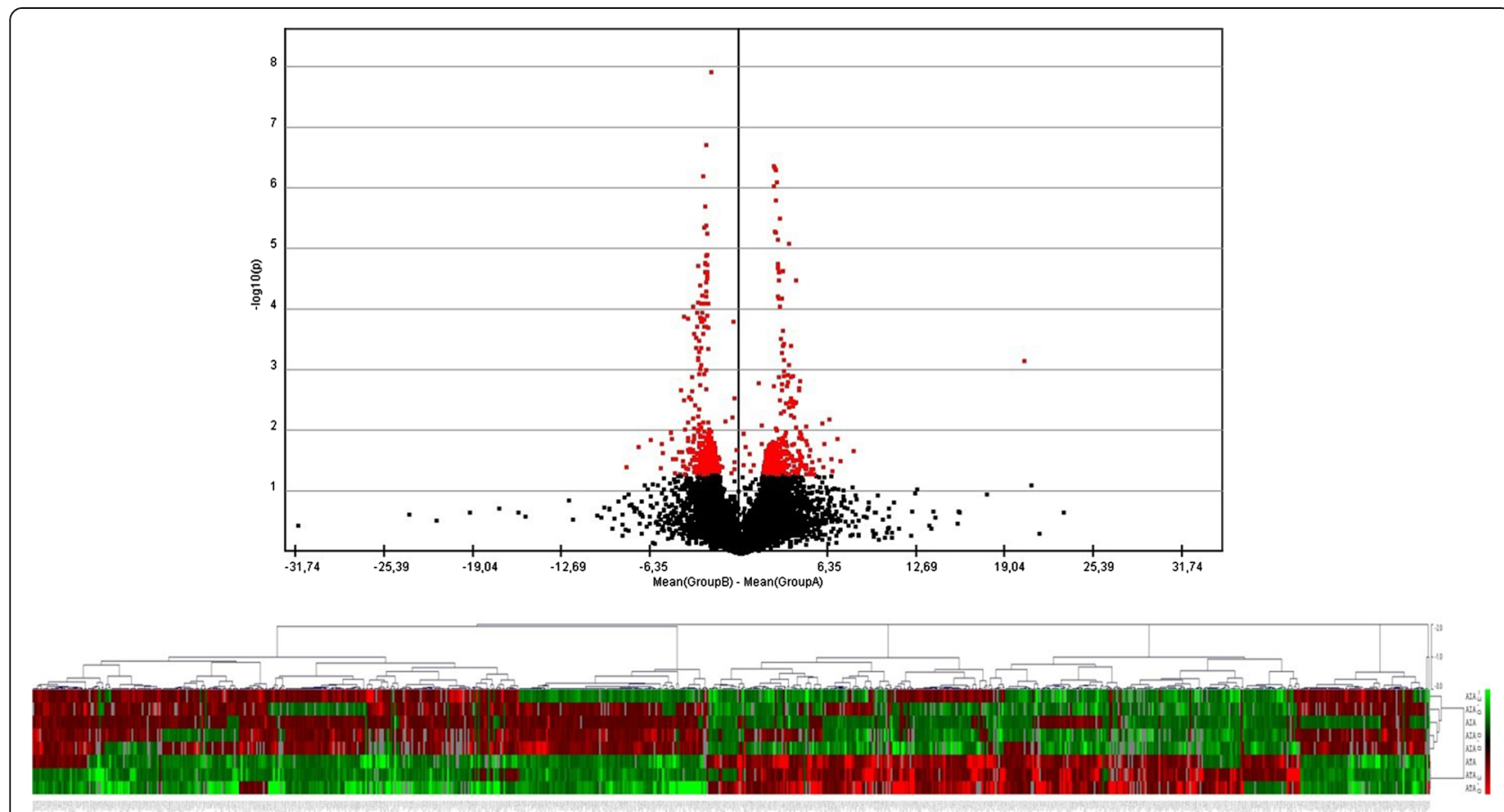

Fig. 2 Volcano plot and result of hierarchical clustering for $p<0.05$ obtained for healthy subjects and aspirin-induced asthma patients

\section{mRNA expression of selected genes}

mRNA expression of CNPY3 in PBMCs in AIA was significantly lower $(-0.41 \pm 2.67)$ than in healthy group $(1.04 \pm 2.69),(p=0.02)$. However, expression of the mRNA of CNPY3 in PBMCs was not significantly different between AIA and ATA $(0.52 \pm 2.15),(p=0.08)$ and ATA $v s$. healthy group ( $p=1.00)$; (Fig. $6 \mathrm{a})$.

mRNA expression of ERAS in PBMCs in AIA was significantly higher $(1.15 \pm 0.23)$ than in healthy group $(-1.32 \pm 0.41),(p=0.03)$. While, expression of the mRNA of ERAS in PBMCs was not significantly different between AIA and ATA $(-0.52 \pm 0.72),(p=0.18)$ and ATA $v s$. healthy group ( $p=0.65)$; (Fig. $6 \mathrm{~b})$.

mRNA expression of FOSL1 in PBMCs in AIA was significantly lower $(-0.66 \pm 2.97)$ than in healthy group $(0.31 \pm 4.83)$, $(p=0.02)$. However, FOSL1 mRNA expression in PBMCs was not significantly changed between AIA and ATA $(-0.09 \pm 3.03),(p=0.54)$ and ATA $v s$. healthy group $(p=0.78)$; (Fig. $6 c)$.

mRNA expression of the following genes in PBMCs was not significantly changed after aspirin-lysine and lysine incubation:

ALOX5 - AIA $(0.01 \pm 0.28)$ vs. ATA $(0.23 \pm 0.35)$, $(p=0.894)$ and healthy volunteers $(-0.04 \pm 0.27) ;(p=$ $0,99)$ (Fig. 7a), ALOX15 - AIA $(-0.05 \pm 0.86) v s$. ATA $(-1.18 \pm 0.75),(p=0.5)$ and healthy volunteers $(-1.07 \pm$ 0.36), $(p=0.52)$; (Fig. 7b).

DOCK 9 - AIA $(0.59 \pm 0.42)$ vs. ATA $(-0.21 \pm 0.26)$, $(p=0.39)$ and healthy volunteers $(-0.12 \pm 0.31),(p=0.42)$;
(Fig. 7c), MARVELD1 - AIA $(-0.37 \pm 0.18)$ vs. ATA $(-0.27 \pm 0.4),(p=0.97)$ and healthy volunteers $(0.35 \pm$ 0.23), $(p=0.15)$; (Fig. 7d).

PARVG - AIA $(-0.35 \pm 1.93)$ vs. ATA $(0.07 \pm 1.2),(p=$ $0.14)$ and healthy volunteers $(-0.12 \pm 0.92),(p=0.77)$; (Fig. 7e), and TLR7 - AIA $(-0.09 \pm 0.33)$ vs. ATA $(-0.33 \pm$ $0.15),(p=0.8)$ and healthy volunteers $(0.04 \pm 0.11)$, $(p=0.9)$; (Fig. 7f).

Moreover, no statistically significant changes were observed in the following genes mRNA expression:

$B M P 2$ - AIA $(-0.22 \pm 0.25)$ vs. ATA $(0.26 \pm 0.23),(p=$ $0.72)$ and healthy volunteers $(-0.20 \pm 0.31),(p=1)$; (Fig. 7g), CSF1 - AIA $(-0.8 \pm 0.28)$ vs. ATA $(-0.03 \pm 0.18),(p=0.23)$ and healthy volunteers $(-0.27 \pm 0.21),(p=0.31)$; (Fig. $7 \mathrm{~h})$.

CXCL11 - AIA $(-0.33 \pm 0.33)$ vs. ATA $(0.4 \pm 0.15),(p=$ $0.41)$ and healthy volunteers $(-0.57 \pm 0.35),(p=0.87)$; (Fig. 7i), DPP9 - AIA $(0.28 \pm 4.12) v s$. ATA $(0.24 \pm 2.34),(p=1)$ and healthy volunteers $(0.16 \pm 3.8),(p=1.0)$; (Fig. $7 \mathrm{j})$.

mRNA expression of GAB3 in PBMCs was also not significantly changed between AIA $(-0.06 \pm 0.13)$ versus ATA $(0.14 \pm 0.25),(p=0.75)$ and healthy patients $(-0.13 \pm$ 0.12), $(p=0.95)$; (Fig. 7k), similarly, TRIP6 in PBMCs AIA $(-0.25 \pm 1.46) \quad$ vs. ATA $(0.26 \pm 2.73), \quad(p=1)$ and healthy patients $(-0.03 \pm 3.43),(p=1)$; (Fig. 71$)$.

Verification of gene expression with quantitative measurement of protein using immunoblotting analysis Comparison of protein expression encoded by selected genes between AIA $(n=6)$, ATA $(n=6)$ and healthy 


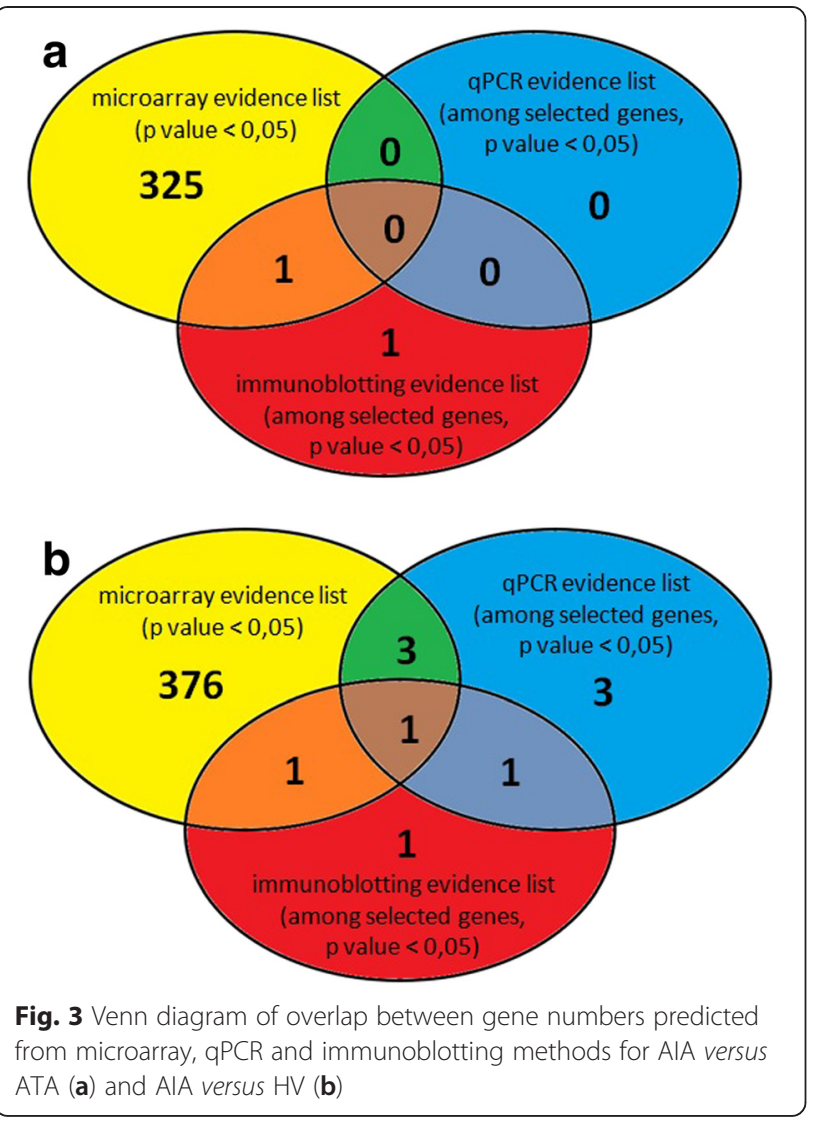

from microarray, qPCR and immunoblotting methods for AlA versus ATA (a) and AIA versus HV (b) volunteers $(n=7)$ groups was done by means of immunoblotting. Quantification of ALOX5, ALOX15, BMP2, CNPY3, CSF1, CXCL11, DOCK9, DPP9, ERAS, FOSL1, GAB3, MARVELD1, PARVG, TLR7, TRIP6 protein levels was performed by measuring the protein product amount after stimulation of PBMCs with lysine aspirin and correcting for obtained protein amount after stimulation of PBMCs with lysine. Further, quantification of protein levels on the basis of obtained bands after stimulation with lysine aspirin and lysine was analyzed on the same gel for each patients. Sharp bands for BMP2, CNPY3, CSF1, CXCL11, DPP9 ERAS, FOSL1, GAB3 and TRIP6 appeared in the expected positions. In the case of other selected genes, no or faint bands (weak signal) were obtained.

\section{Selected proteins expression}

CNPY3 protein expression in PBMCs was not significantly changed between AIA $(0.26 \pm 0.55)$ vs. ATA $(-0.33 \pm 0.16),(p=0.58)$ and healthy patients $(-0.56 \pm$ $0.47),(p=0.41)$; (Fig. 8a), same as ERAS protein expression - AIA $(0.68 \pm 0.21) v s$. ATA $(-0.67 \pm 0.75),(p=0.37)$ and healthy patients $(-0.56 \pm 0.67),(p=0.38)$; (Fig. $8 \mathrm{~b})$.

Protein expression of FOSL1 in PBMCs in AIA was significantly lower $(-0.86 \pm 0.08)$ in comparison to ATA $(0.39 \pm 0.42),(p=0.046)$ and to healthy subjects $(0.9 \pm$ $0.27)$, ( $p=0.007)$. However, FOSL1 protein expression in PBMCs was not significantly changed between ATA $v s$. healthy group ( $p=0.487)$; (Fig. $8 \mathrm{c}$ ). Immunobloting results are shown in the Fig. 9.

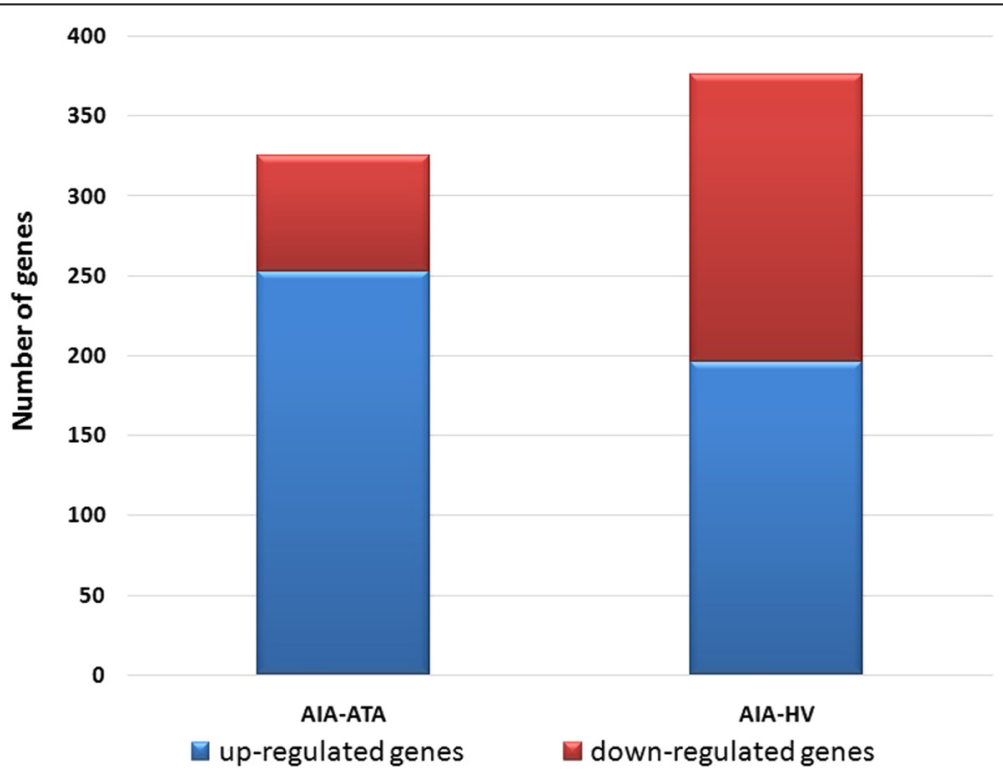

Fig. 4 Number of genes with differential expression between groups with up-regulated genes being predominant on AIA versus ATA and AIA versus healthy volunteers. PBMCs were separated from blood of three groups of subjects - 11 AIA, 7 ATA and 15 HV and stimulated by either lysine aspirin or lysine as a control. The gene expression presented was analyzed utilizing microarray technique 


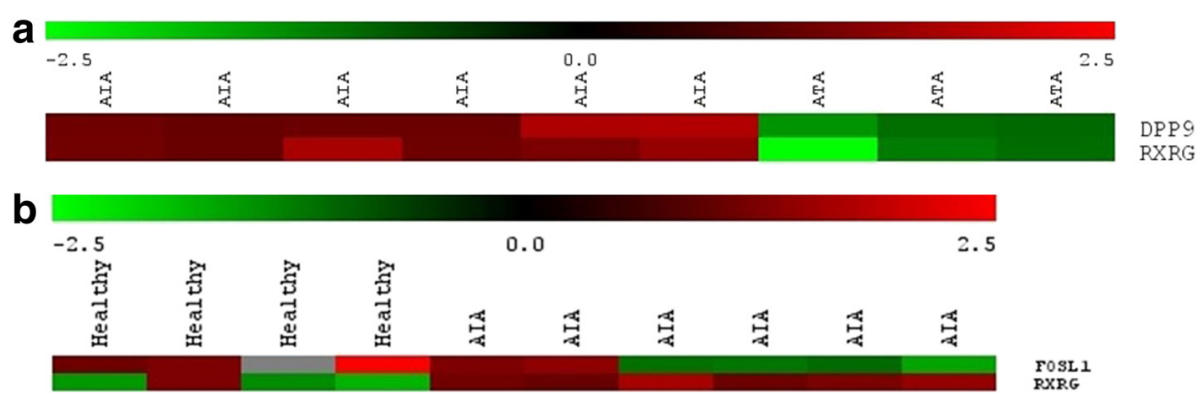

Fig. 5 Heat map of selected genes of AIA and ATA subjects $(p<0.05)(\mathbf{a})$, as well as healthy controls and AlA subjects $(p<0.05)(\mathbf{b})$

Changes in expression of the other proteins were not statistically significant: BMP2 protein expression in PBMCs was not significantly changed between AIA $(0.28 \pm 0.5) v s$. ATA $(-0.36 \pm 0.46),(p=0.58)$ and healthy patients $(-0.76 \pm$ $0.26),(p=0.2)$; (Fig. 10a), the same as CSF1 protein - AIA $(-0.85 \pm 0.2)$ vs. ATA $(0.39 \pm 0.6),(p=0.34)$ and healthy patients $(-0.59 \pm 1.0),(p=0.9)$; (Fig. 10b), and CXCL11 - AIA $(-0.25 \pm 0.67) v s$. ATA $(-0.46 \pm 0.28),(p=0.94)$ and healthy patients $(0.77 \pm 0.28),(p=0.28)$; (Fig. 10c).

DPP9 protein expression in PBMCs was not significantly changed between AIA $(-0.37 \pm 0.4)$ vs. ATA $(-0.2 \pm 0.12)$, $(p=0.91)$ and healthy patients $(-0.07 \pm 0.16),(p=0.76)$; (Fig. 10d), the same as GAB3 protein expression - AIA $(-0.12 \pm 0.16) v s$. ATA $(0.06 \pm 0.18),(p=0.74)$ and healthy patients $(-0.07 \pm 0.14),(p=0.98) ;($ Fig. 10e), and TRIP6 protein - AIA $(0.66 \pm 0.5)$ vs. ATA $(-0.14 \pm 0.28),(p=0.54)$ and healthy patients $(0.08 \pm 0.55),(p=0.72)$; (Fig. 10f).

\section{Discussion}

Considering the genetic background of AIA, more than 100 genetic association studies have attempted to discover the numerous genetic variants related to development of AIA. However, the majority of these results have not been replicated in other, independent studies. Moreover, to the best of our knowledge, two published papers based on both microarray study and qPCR confirmation reveal the involvement of individual genes in the pathogenesis of AIA. However neither of which were also confirmed in other studies and population.

The first, whole-genome study [36] demonstrated that galactin-10 mRNA is overexpressed in peripheral blood cells of AIA compared to ATA patients and controls.

Table 4 Differences in gene expression obtained in whole genome scan using CDNA microarrays

\begin{tabular}{llllll}
\hline No & Gene symbol & AIA mean & ATA mean & $p$ value & FDR \\
1 & DPP9 & 1,29 & $-1,20$ & $1,23 \cdot 10^{-5}$ & 0,009 \\
2 & RXRG & 1,28 & $-1,80$ & $2,61 \cdot 10^{-4}$ & 0,089 \\
No & Gene symbol & AIA mean & HV mean & p value & FDR \\
3 & FOSL1 & $-0,39$ & 2,42 & 0,044 & 1,189 \\
\hline
\end{tabular}

Galactin-10 had been previously implicated in mucosal inflammatory processes including cell adhesion [37], chemoattraction [38] and cell activation [39]. Whereas, the second study [40] showed two genes - CNKSR3 and SPTBN2 which expression in PBMCs differentiates between AIA and ATA, but neither CNKSR3 nor SPTBN2 has described relationship with asthma and aspirin.

As in previous whole genome studies, the main aim of our investigation was to compare the AIA genetic profile against ATA and HV in PBMCs by microarray studies and then confirm it on protein level. The verification on two molecular levels was necessary because mRNA levels cannot be utilized as surrogates for corresponding protein levels. Although RNAs are primordial molecules, proteins are the molecules of life and it is estimated that only less than $40 \%$ of cellular protein levels can be predicted from mRNA measurements [41]. The most known, presumable reasons for the poor correlations reported in literature between the level of mRNA and protein are: (a) many complicated and varied post-transcriptional mechanisms involved in turning mRNA into protein - the cell can control the levels of gene at transcriptional level and/ or translational level [42]; (b) difference in half-lives of proteins as the result of varied protein synthesis and degradation depending on a number of different conditions; (c) significant amount of error in mRNA/protein studies $[43,44]$. Intriguingly, genes with certain combinations of mRNA and protein half-lives share common functions, indicating that they evolved under similar constraints such as abrupt respond to stimulus [41, 45-47]. Most mRNAs and especially proteins are stable unless genes need to respond quickly to a stimulus [41]. However, measurements performed at mRNA and protein levels are complementary and both are necessary for a complete understanding how the cell works [48].

On the basis of obtained results, we identified three genes whose expression profiles significantly differed between AIA vs. ATA and/or AIA vs. healthy subjects in PBMCs of Caucasian population. We demonstrated significant decrease in expression of FOSL1 (encoding FRA1) at either mRNA or protein level in patients diagnosed 


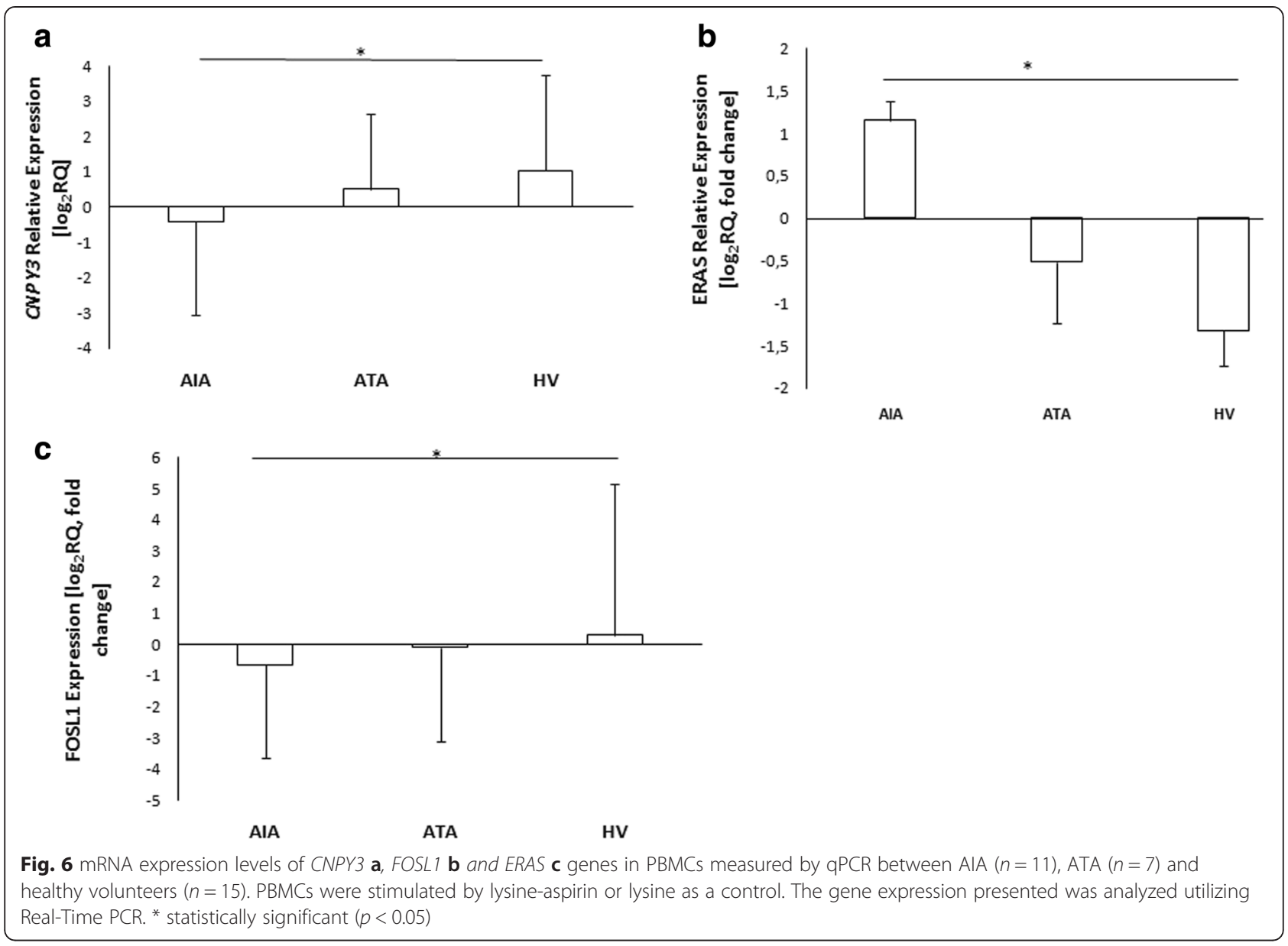

with AIA in comparison to ATA and controls. FOSL1 is a part of AP-1 - transcription factor that regulates target gene expression in response to various pro-oxidants, inflammatory cytokines including TGF $\beta 1[49,50]$, environmental toxicants, carcinogens and pathogens. These gene products mediate oxidative stress and inflammatory responses, as well as cell growth and tumorgenesis [51]. Additionally, TGF- $\beta 1$ promoter $(509 \mathrm{C} / \mathrm{T})$ polymorphism has been reported to contribute to the development of AIA with rhinosinusitis by increasing TGF- $\beta$ production in the nasal mucosa and/or polyp tissues of patients with AIA [52]. Tang et al. showed that aspirin-treated bone marrow cells have significantly improved immunomodulatory function, as indicated by upregulation of regulatory $\mathrm{T}$ cells and downregulation of Th17 cells via, inter alia TGF- $\beta 1$ pathway [53].

Moreover, FOSL1 regulates the expression of genes controlling tissue/cell remodeling, mainly at transcriptional level [54-56]. Rajasekaran et al. [57] have recently shown that $\mathrm{FRA1}^{-1-}$ mice are more susceptible than wildtype mice to bleomycin - induced fibrosis, suggesting that this transcriptional factor is involved in pulmonary protection. To emphasize this hypothesis, downregulation of
FOSL1 was also observed in malignant human bronchial epithelial cells [55] and non-small-cell lung cancer [58] compared to normal bronchial epithelium.

Comparison of genetic profile between AIA and healthy controls has also demonstrated significantly increased expression of ERAS in AIA. Actually the role of this gene is restricted to the tumor - like growth properties of embryonic stem cells [59] and chemotherapy resistance [60]. However, ERAS belongs to GTPase Ras protein family engaged in airway smooth muscle growth and bronchoconstriction of airways in response to stimuli [61]. Among all proteins that belong to Ras superfamily, Rho kinase has emerged as a potential target for the treatment of airway hyperresponsiveness in asthma [62]. Additionally, arachidonic acid (AA) can activate Rho kinase by binding to the C-terminal part of the coiled-coil domain of Rho kinase, which acts as an auto-inhibitor domain [63-65]. Rho kinase may also be involved in eotaxin and cytokine (IL-5, IL-13) production [66] and in secretion of matrix metalloproteinase - 9 (MMP-9), tightly associated with fibrosis in asthma and chronic obstructive pulmonary disease (COPD) $[67,68]$. It is worth mentioning, as the extent of Ras activation in T cells appears to drive Th2 

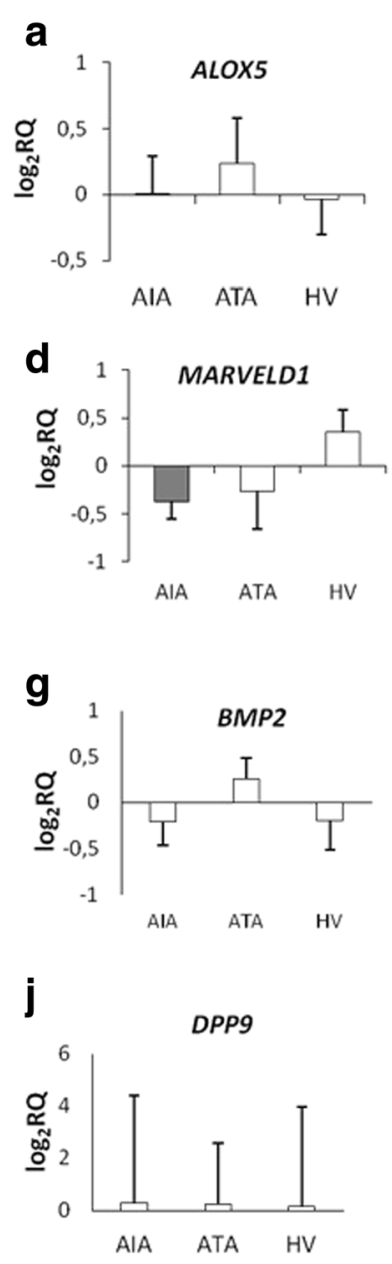
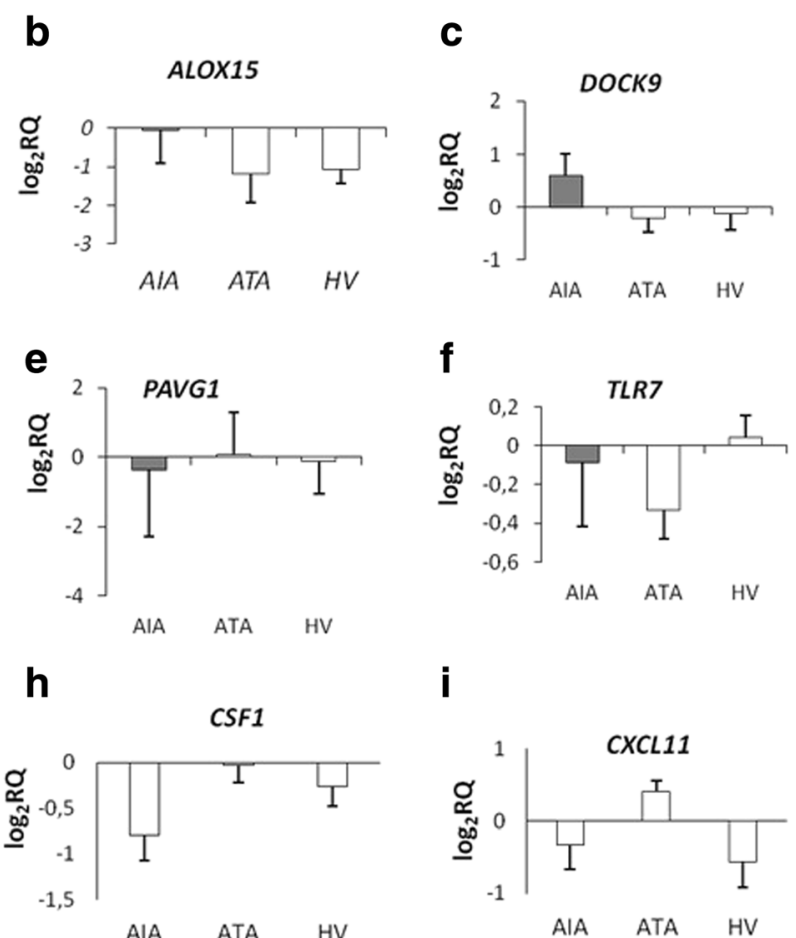

i
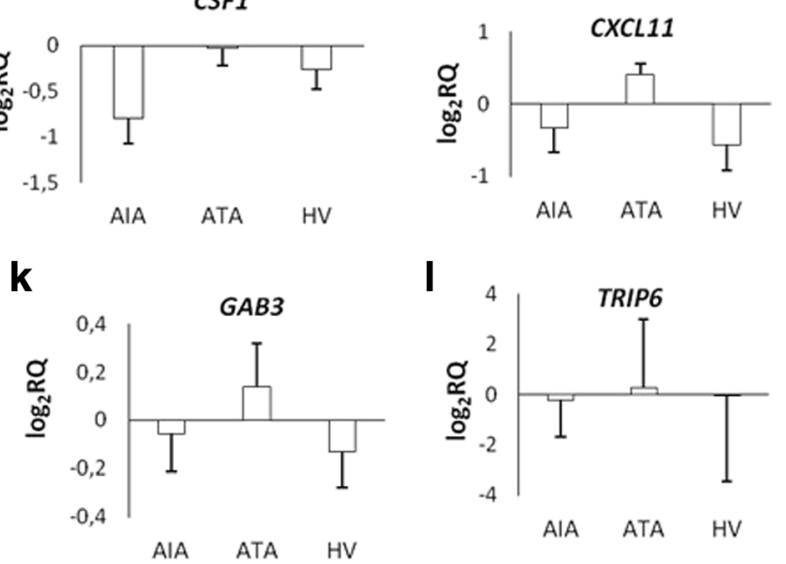

Fig. 7 Box plot for mRNA expression levels of ALOX5 a, ALOX15 b, DOCK9 c, MARVELD1 d, PARVG e, TLR7 f BMP2 g, CSF1 h, CXCL11 i, DPP9 j, GAB3 $\mathbf{k}$, and TRIP6 I genes in PBMCs measured by qPCR between AIA $(n=11)$, ATA $(n=7)$ and healthy volunteers $(n=15)$. PBMCs were stimulated by lysine-aspirin or lysine as a control. The gene expression presented was analyzed utilizing Real-Time PCR

dependent eosinophilic airway inflammation and allergeninduced airway hyperresponsiveness [69]. Much evidence indicates also that Ras GTPases appear to regulate reactive oxygen species (ROS) production and oxidants function as effector molecules for the small GTPases [70-73]. Rac1 has been demonstrated to act upstream of AA - metabolizing enzymes, such as $\mathrm{PLA}_{2}$ [74, 75], 5-LOX [76-78] and COX-2 [79] and thus some reports show that AA metabolism modulates NADPH oxidase and mitochondrial ROS production [80].

The misregulation of the redox signaling of Ras with its downstream cascades also has been linked to various disorders linked with immune system [81]. According to Wells et al. [82], Ras-dependent Raf-MEK1/2-ERK1/2 pathway takes part in postnatal modulation of a host's defenses and the inflammation of $\mathrm{T}$ lymphocytes. In a mouse allergic asthma model, the activation of Ras in $\mathrm{T}$ cells controls the development of Th2-dependent eosinophilic airway inflammation and airway hyperresponsiveness. Specific inhibitors focusing on Rasmediated signaling pathways would be thus helpful in treatment approach of asthma [69].

Although ERAS was one of the genes indicating association with aspirin-induced asthma in our study, there are only single data supporting its role. Nevertheless, recently, Park et al. [83] have shown a strong association between the SNPs (14444 T > G and $41170 \mathrm{C}>\mathrm{G}$ ) within RAB1A (Ras protein subfamily member) and the aspirininduced decrease in $\mathrm{FEV}_{1}$. The authors indicate also, that genetic alteration of the member RAS oncogene family may be related to the development of asthma and ASA hypersensitivity through the modulation of intracellular protein trafficking.

Multiple points of overproduction or underproduction of critical inflammatory mediators may be determined by metabolism through the Ras family GTPase pathway. The 


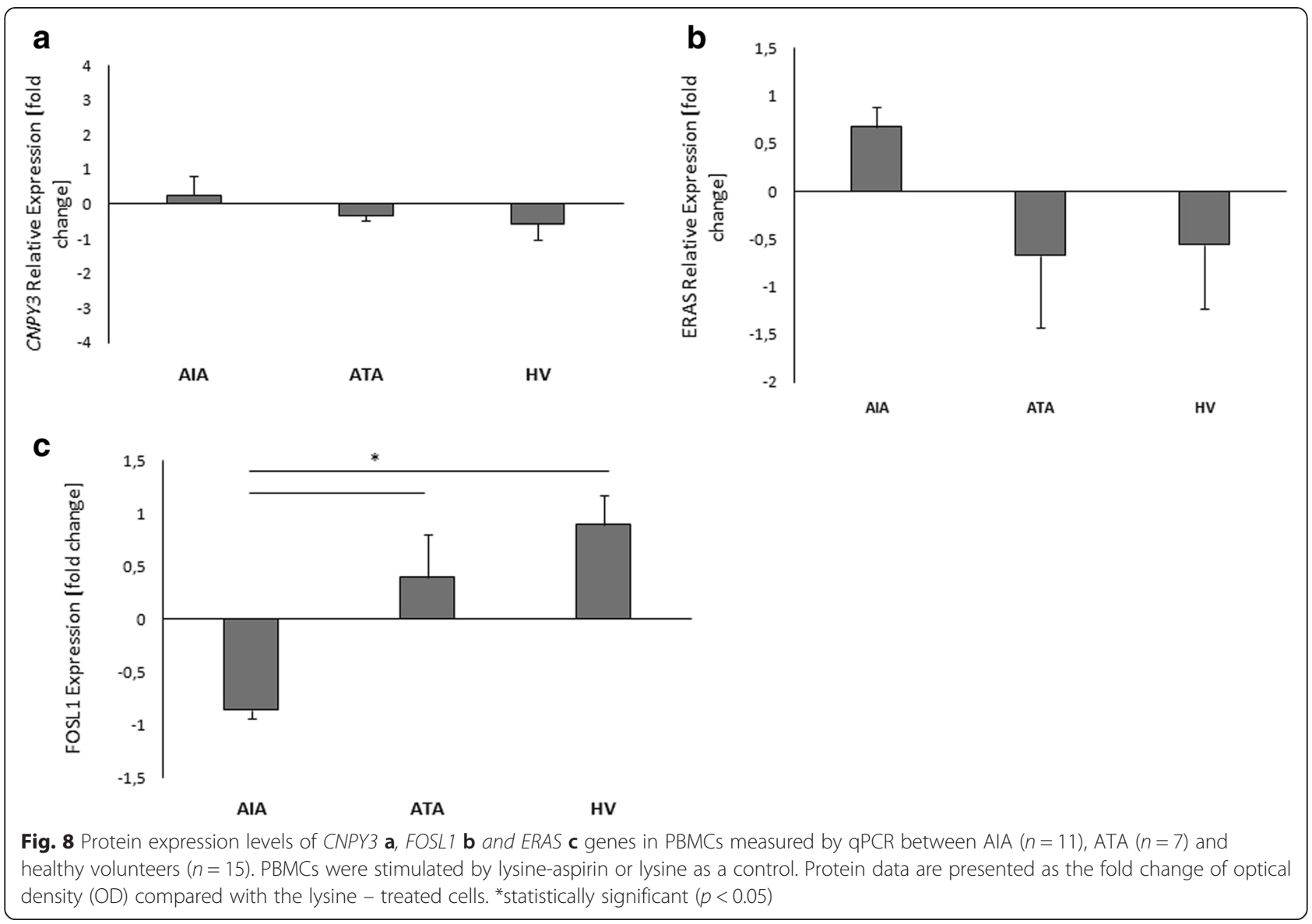

release of specific granules from platelets, eosinophils, and neutrophils depends on the phosphorylation of the Ras family proteins [81], but detailed mechanism associated with aspirin-induced asthma needs to be evaluated.

Significantly reduced expression of CNPY3 at mRNA level in AIA in comparison to healthy controls may indicate a profound defect in stimulus responsiveness. CNPY3 is an endoplasmic reticulum - resident chaperone that is required for maturation/ glucosylation and surface trafficking of TLR4 [84]. Activated TLR4 can directly or indirectly affect the function of regulatory $\mathrm{T}$ cells, thus influencing the Th1/Th2 imbalance and reducing inflammatory responses [85-87].

It is well known, that TLR4 is important component in the innate immune response to lipopolysaccharide (LPS) of gram-negative bacteria and the fusion protein of respiratory syncytial virus (RSV) [88]. Therefore, CNPY3 knockdown led to significant defect in RSV and LPS responsiveness and limit innate immune responses $[84,89]$. By contrast, patients with AIA much more frequently suffer from virus infection [90] and RSV is probably one of the trigger predisposing to aspirin hypersensitivity [91].
TLR4 is activated following binding of LPS, and a series of downstream phosphorylation and dephosphorylation events eventually leads to the activation of transcription factors that regulate inflammatory factors including interferon, tumor necrosis factor; it also induces antigen-presenting cell maturation and promotes a Th0 to Th1 shift [85, 92]. According to Steinke et al. [93], high levels of mentioned IFN- $\gamma$ distinguish AERD (aspirin-exacerbated respiratory disease) from aspirin tolerant asthma and underlie the robust constitutive and aspirin-induced secretion of CysLTs that characterize this disorder, as AERD is associated with eosinophils maturing locally in a high interferon (IFN)- $\gamma$.

To better understand the contribution of TLR4 to aspirin-induced asthma pathogenesis, additional studies are needed to determine the contribution of CNPY3 in aspitin-induced asthma.

Our data also demonstrate that similar microarray scores for different genes do not necessarily mean that similar qPCR scores was obtained. This finding presumably reflects the different hybridization kinetics of the probe sets for each gene. Furthermore, varied priming methods and increased distance between the location of 

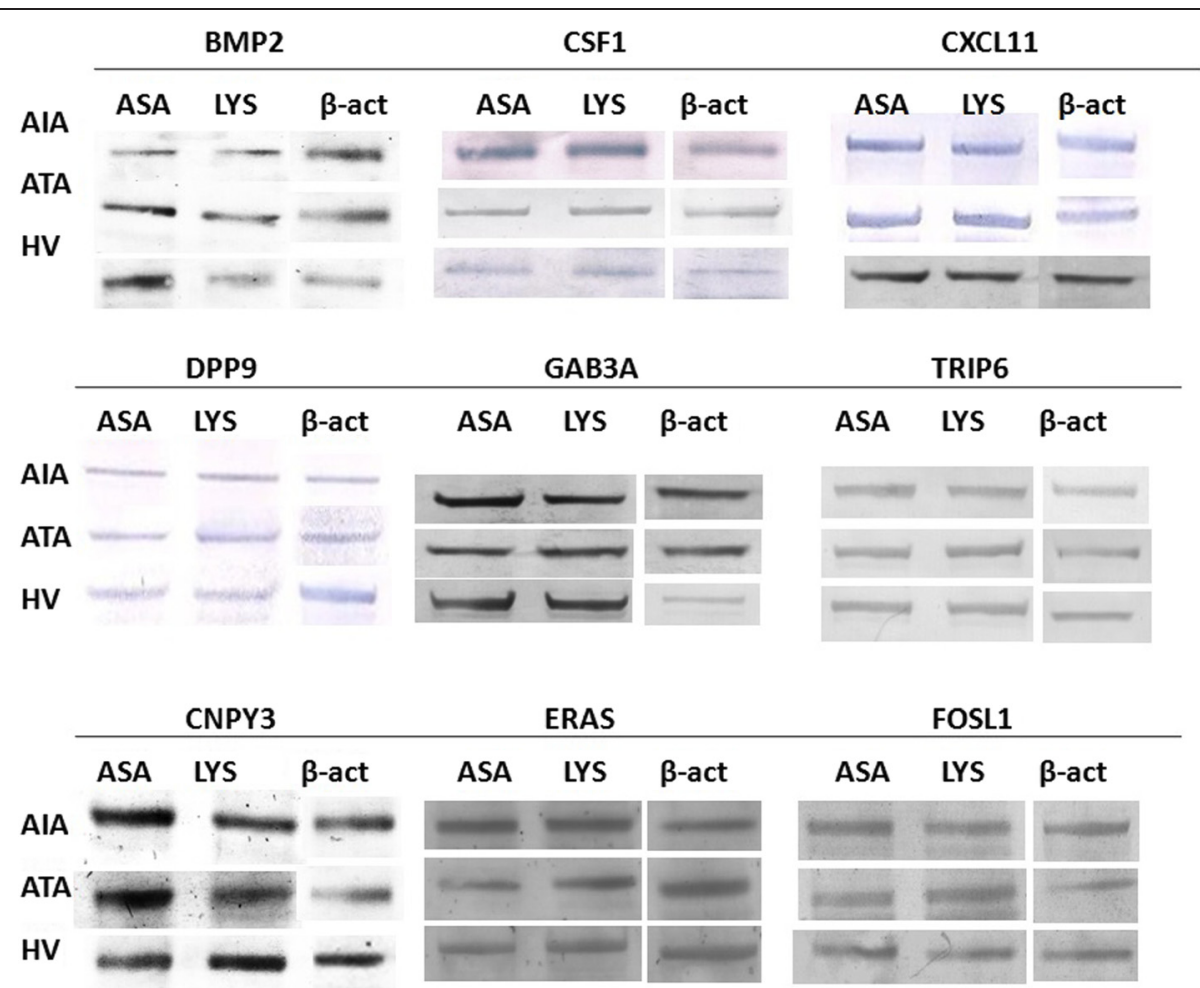

Fig. 9 Protein expression measured by immunoblotting between AIA, ATA and healthy volunteers. The blots shown are a representative of at least six separate experiments that gave similar results
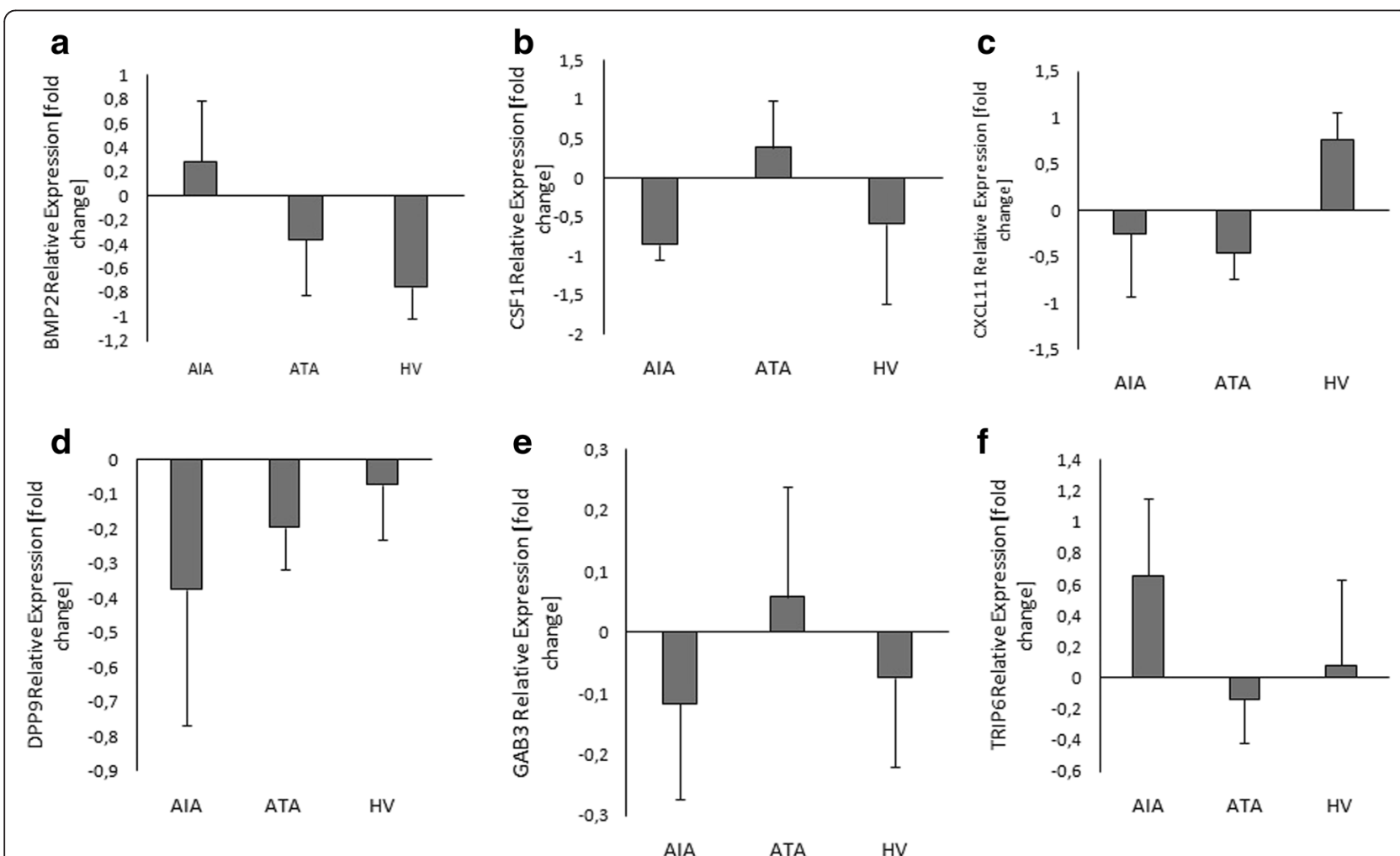

Fig. 10 Box plot for protein expression levels of BMP2 a, CSF1 b, CXCL11 c, DPP9 d, GAB3 e and TRIP6 $\mathbf{f}$ genes in PBMCs measured by qPCR between AIA $(n=11)$, ATA $(n=7)$ and healthy volunteers $(n=15)$. Data are presented as the fold change of optical density (OD) compared with the lysine - treated cells 
the PCR primers and microarray probes on a given gene can also affect the results of qPCR and microarray experiments. In addition, data normalization fundamentally differs between microarray analysis and qPCR, the former requiring global normalization, while the latter generally utilizes the expression of one reference gene against which all other gene expression is calibrated. Therefore, on the basis of the qPCR data that we obtained, it is generally not feasible to predict the true expression level of one gene based on the microarray expression score of another.

\section{Conclusions}

To sum up, altered expression of three genes: ERAS, CNPY3 and FOSL1 have been reported at mRNA level in PBMCs of Caucasian aspirin-sensitive asthmatics as opposed to healthy volunteers. In the case of FOSL1, this difference was also confirmed at protein level, both - between AIA vs. ATA and AIA vs. HV. To our knowledge, this is the first whole-genome study for AIA that points out the positive association between ERAS, CNPY3, FOSL1 and NSAIDs metabolism. However, some previous studies have indicated participation of these genes in pathways significant for pathomechanism of AIA resulting in tissue/cell remodeling and airway hyperresponsiveness. Although our study included small number of patients, it allowed to perform statistical analysis. Undoubtedly, further studies in a larger number of cases and of other ethnicity are necessary to establish an exact functional link among the detected alternations in expression of CNPY3, ERAS and FOSL1 with pathology of AIA.

\section{Additional file}

Additional file 1. Western Blot protocol. (PDF $176 \mathrm{~kb}$ )

\footnotetext{
Abbreviations

15-HETE: 15 - hydroxyeicosatetranoic acid; 15-LOX: 15 - lipooxygenase; 5-LOX: 5-lipoxygenase; AA: arachidonic acid; AERD: aspirin-exacerbated respiratory disease; AIA: aspirin-induced asthma; ALOX15: arachidonate 15-lipoxygenase; ALOX5: arachidonate 5-lipoxygenase; ASA: aspirin; ATA: aspirin tolerant asthma; BMP2: bone morphogenetic protein 2; CNKSR3: CNKSR family member 3; CNPY3: canopy FGF signaling regulator; COX: cyclooxygenase; CSF1: colony stimulating factor 1 (macrophage); CXCL11: chemokine (C-X-C motif) ligand 11; CysLTR1: type 1 receptor for cysteinyl leukotriens; DOCK9: dedicator of cytokinesis 9; DPP9: dipeptidylpeptidase 9; ERAS: ES cell expressed Ras; FDR: false discovery rate; FEV1: forced expiratory volume in $1 \mathrm{~s}$; FOSL1: FOS-like antigen 1; GAB3: GRB2-associated binding protein $3 ; \mathrm{HV}$ : healthy volunteers; LPS: lipopolysaccharide; Lys - ASA: Iysine aspirin; MA: mast cells; MARVELD1: MARVEL domain containing 1; NSAIDs: nonsteroidal anti-inflammatory drugs; PARVG: parvin, gamma; PBMCs: peripheral blood mononuclear cells; PGE2: prostaglandin E2; PLA2: phospholipase A2; qPCR: quantitative PCR; RSV: respiratory syncytial virus; RXRG: retinoid X receptor gamma; SPTBN2: spectrin; TGFB1: transforming growth factor, beta 1; TLR7: toll-like receptor 7; TRIP6: thyroid hormone receptor interactor 6 .
}

\section{Competing interests}

The authors declare that they have no competing interests.

\section{Authors' contributions}

Dr Wieczfinska takes responsibility for the integrity of the data and accuracy of the data analysis. Dr Kacprzak and Dr Wieczfinska designed the study, contributed to clinical data collection and RT-PCR analysis as well as Western Blot analysis, data collection from all methods, statistical analysis and writing of the manuscript. Dr Pospiech performed microarray experiment and contributed to statistical data analysis obtained from microarray. Dr Sokolowska designed the study and contributed to clinical data collection. Dr Nowakowska contributed to perform microarray experiment. Dr Pniewska contributed to Western Blot analysis. Prof. Bednarek contributed to statistical data analysis obtained from microarray. Dr Kuprys - Lipinska contributed to recruitment of patients and clinical data collection. Prof. Kuna contributed to recruitment of patients and clinical data collection. Prof Pawliczak: designed the study, contributed to clinical data collection and critical review of the manuscript. All authors read and approved the final manuscript.

\section{Acknowledgements}

We thank the Foundation for Development of Polish Pharmacy and Medicine, the National Science Centre of Poland and the Medical University of Lodz for financial support by research grants.

\section{Author details}

${ }^{1}$ Department of Immunopathology, Medical University of Lodz, Chair of Allergology, Immunology and Dermatology, 7/9 Zeligowskiego, 90-752 Lodz, Poland. ${ }^{2}$ Department of Molecular Carcinogenesis, Medical University of Lodz, Chair of Molecular Medicine and Biotechnology, Lodz, Poland. ${ }^{3}$ Swiss Institute of Allergy and Asthma Research (SIAF), University of Zurich, Christine Kühne-Center for Allergy Research and Education, Davos, Switzerland.

${ }^{4}$ Department of Internal Medicine, Asthma and Allergy, Medical University of Lodz, Lodz, Poland.

Received: 21 November 2015 Accepted: 25 November 2015 Published online: 09 December 2015

\section{References}

1. Szczeklik A, Nizankowska E. Clinical features and diagnosis of aspirin induced asthma. Thorax. 2000;55 Suppl 2:S42-4.

2. Campo P, Ayuso P, Salas M, Plaza MC, Cornejo-García JA, Doña I, et al. Mediator release after nasal aspirin provocation supports different phenotypes in subjects with hypersensitivity reactions to NSAIDs. Allergy. 2013;68(8):1001-7.

3. Stevenson DD, Szczeklik A. Clinical and pathologic perspectives on aspirin sensitivity and asthma. J Allergy Clin Immunol. 2006;118(4):773-86. quiz 787-778.

4. Szczeklik A, Nizankowska E, Duplaga M. Natural history of aspirin-induced asthma. AIANE Investigators. European Network on Aspirin-Induced Asthma. Eur Respir J. 2000;16(3):432-6.

5. Gomes E, Cardoso MF, Praça F, Gomes L, Mariño E, Demoly P. Self-reported drug allergy in a general adult Portuguese population. Clin Exp Allergy. 2004;34(10):1597-601.

6. Kasper L, Sladek K, Duplaga M, Bochenek G, Liebhart J, Gladysz U, et al. Prevalence of asthma with aspirin hypersensitivity in the adult population of Poland. Allergy. 2003;58(10):1064-6.

7. Vally $\mathrm{H}$, Taylor ML, Thompson PJ. The prevalence of aspirin intolerant asthma (AIA) in Australian asthmatic patients. Thorax. 2002;57(7):569-74.

8. Kasper $\measuredangle$, Sładek K, Bochenek G, Duplaga M, Szczeklik A. The frequency of hypersensitivity to non-steroidal anti-inflammatory drugs (NSAIDs) in the population of adult asthmatics in Poland based on an epidemiological questionnaire. Pneumonol Alergol Pol. 2009;77(5):431-9.

9. Mascia K, Haselkorn T, Deniz YM, Miller DP, Bleecker ER, Borish L, et al. Aspirin sensitivity and severity of asthma: evidence for irreversible airway obstruction in patients with severe or difficult-to-treat asthma. J Allergy Clin Immunol. 2005;116(5):970-5.

10. Lee JH, Haselkorn T, Borish L, Rasouliyan L, Chipps BE, Wenzel SE. Risk factors associated with persistent airflow limitation in severe or difficult-to-treat asthma: insights from the TENOR study. Chest. 2007;132(6):1882-9.

11. Mascia K, Borish L, Patrie J, Hunt J, Phillips CD, Steinke JW. Chronic hyperplastic eosinophilic sinusitis as a predictor of aspirin-exacerbated respiratory disease. Ann Allergy Asthma Immunol. 2005;94(6):652-7. 
12. Kalyoncu AF, Karakaya G, Sahin AA, Bariş YI. Occurrence of allergic conditions in asthmatics with analgesic intolerance. Allergy. 1999:54(5):428-35.

13. Berges-Gimeno MP, Simon RA, Stevenson DD. The natural history and clinical characteristics of aspirin-exacerbated respiratory disease. Ann Allergy Asthma Immunol. 2002:89(5):474-8.

14. Flamand N, Surette ME, Picard S, Bourgoin S, Borgeat P. Cyclic AMPmediated inhibition of 5-lipoxygenase translocation and leukotriene biosynthesis in human neutrophils. Mol Pharmacol. 2002;62(2):250-6.

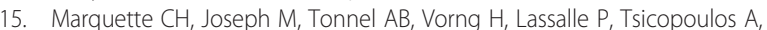
et al. The abnormal in vitro response to aspirin of platelets from aspirinsensitive asthmatics is inhibited after inhalation of nedocromil sodium but not of sodium cromoglycate. Br J Clin Pharmacol. 1990;29(5):525-31.

16. Yoshida S, Amayasu H, Sakamoto H, Onuma K, Shoji T, Nakagawa H, et al. Cromolyn sodium prevents bronchoconstriction and urinary LTE4 excretion in aspirin-induced asthma. Ann Allergy Asthma Immunol. 1998;80(2):171-6.

17. Sestini P, Armetti L, Gambaro G, Pieroni MG, Refini RM, Sala A, et al. Inhaled PGE2 prevents aspirin-induced bronchoconstriction and urinary LTE4 excretion in aspirin-sensitive asthma. Am J Respir Crit Care Med. 1996;153(2):572-5.

18. Tanioka T, Nakatani Y, Semmyo N, Murakami M, Kudo I. Molecular identification of cytosolic prostaglandin E2 synthase that is functionally coupled with cyclooxygenase-1 in immediate prostaglandin E2 biosynthesis. J Biol Chem. 2000;275(42):32775-82.

19. Murakami M, Naraba H, Tanioka T, Semmyo N, Nakatani $Y$, Kojima F, et al. Regulation of prostaglandin E2 biosynthesis by inducible membraneassociated prostaglandin E2 synthase that acts in concert with cyclooxygenase-2. J Biol Chem. 2000;275(42):32783-92.

20. Murakami M, Nakashima K, Kamei D, Masuda S, Ishikawa Y, Ishii T, et al Cellular prostaglandin E2 production by membrane-bound prostaglandin E synthase-2 via both cyclooxygenases-1 and -2. J Biol Chem. 2003;278(39):37937-47

21. Liu T, Laidlaw TM, Katz HR, Boyce JA. Prostaglandin E2 deficiency causes a phenotype of aspirin sensitivity that depends on platelets and cysteinyl leukotrienes. Proc Natl Acad Sci U S A. 2013;110(42):16987-92.

22. Liu T, Laidlaw TM, Feng C, Xing W, Shen S, Milne GL, et al. Prostaglandin E2 deficiency uncovers a dominant role for thromboxane A2 in house dust mite-induced allergic pulmonary inflammation. Proc Natl Acad Sci U S A. 2012;109(31):12692-7.

23. Lundequist A, Nallamshetty SN, Xing W, Feng C, Laidlaw TM, Uematsu S, et al. Prostaglandin E(2) exerts homeostatic regulation of pulmonary vascular remodeling in allergic airway inflammation. J Immunol. 2010;184(1):433-41.

24. Laidlaw TM, Kidder MS, Bhattacharyya N, Xing W, Shen S, Milne GL, et al. Cysteinyl leukotriene overproduction in aspirin-exacerbated respiratory disease is driven by platelet-adherent leukocytes. Blood. 2012;119(16):3790-8.

25. Pitchford SC, Momi S, Giannini S, Casali L, Spina D, Page CP, et al. Platelet P-selectin is required for pulmonary eosinophil and lymphocyte recruitment in a murine model of allergic inflammation. Blood. 2005;105(5):2074-81.

26. Kornerup KN, Salmon GP, Pitchford SC, Liu WL, Page CP. Circulating platelet-neutrophil complexes are important for subsequent neutrophil activation and migration. J Appl Physiol. 2010;109(3):758-67.

27. Szczeklik A, Gryglewski RJ, Czerniawska-Mysik G, Zmuda A. Aspirin-induced asthma. Hypersensitivity to fenoprofen and ibuprofen in relation to their inhibitory action on prostaglandin generation by different microsomal enzymic preparations. J Allergy Clin Immunol. 1976;58(1 PT 1):10-8.

28. Kowalski ML, Ptasinska A, Bienkiewicz B, Pawliczak R, DuBuske L. Differential effects of aspirin and misoprostol on 15-hydroxyeicosatetraenoic acid generation by leukocytes from aspirin-sensitive asthmatic patients. J Allergy Clin Immunol. 2003;112(3):505-12.

29. Kowalski ML, Ptasinska A, Jedrzejczak M, Bienkiewicz B, Cieslak M, Grzegorczyk J, et al. Aspirin-triggered 15-HETE generation in peripheral blood leukocytes is a specific and sensitive Aspirin-Sensitive Patients Identification Test (ASPITest). Allergy. 2005;60(9):1139-45.

30. Marom Z, Shelhamer JH, Kaliner M. Effects of arachidonic acid monohydroxyeicosatetraenoic acid and prostaglandins on the release of mucous glycoproteins from human airways in vitro. J Clin Invest. 1981;67(6):1695-702.

31. Salari $H$, Schellenberg RR. Stimulation of human airway epithelial cells by platelet activating factor (PAF) and arachidonic acid produces 15-hydroxyeicosatetraenoic acid (15-HETE) capable of contracting bronchial smooth muscle. Pulm Pharmacol. 1991;4(1):1-7.
32. Cheong HS, Park SM, Kim MO, Park JS, Lee JY, Byun JY, et al. Genome-wide methylation profile of nasal polyps: relation to aspirin hypersensitivity in asthmatics. Allergy. 2011;66(5):637-44.

33. Reiner A, Yekutieli D, Benjamini Y. Identifying differentially expressed genes using false discovery rate controlling procedures. Bioinformatics. 2003;19(3):368-75.

34. Keselman HJ, Cribbie R, Holland B. Controlling the rate of Type I error over a large set of statistical tests. Br J Math Stat Psychol. 2002;55(Pt 1):27-39.

35. Pawitan Y, Michiels S, Koscielny S, Gusnanto A, Ploner A. False discovery rate, sensitivity and sample size for microarray studies. Bioinformatics. 2005;21(13):3017-24

36. Devouassoux G, Pachot A, Laforest L, Diasparra J, Freymond N, Van Ganse E, et al. Galectin-10 mRNA is overexpressed in peripheral blood of aspirin-induced asthma. Allergy. 2008;63(1):125-31.

37. Kuwabara I, Liu FT. Galectin-3 promotes adhesion of human neutrophils to laminin. J Immunol. 1996;156(10):3939-44.

38. Sano H, Hsu DK, Yu L, Apgar JR, Kuwabara I, Yamanaka T, et al. Human galectin-3 is a novel chemoattractant for monocytes and macrophages. J Immunol. 2000;165(4):2156-64.

39. Yamaoka A, Kuwabara I, Frigeri LG, Liu FT. A human lectin, galectin-3 (epsilon bp/Mac-2), stimulates superoxide production by neutrophils. J Immunol. 1995;154(7):3479-87.

40. Shin S, Park JS, Kim YJ, Oh T, An S, Park CS. Differential gene expression profile in PBMCs from subjects with AERD and ATA: a gene marker for AERD. Mol Genet Genomics. 2012;287(5):361-71.

41. Schwanhäusser B, Busse D, Li N, Dittmar G, Schuchhardt J, Wolf J, et al. Global quantification of mammalian gene expression control. Nature. 2011;473(7347):337-42.

42. Cho RJ, Campbell MJ, Winzeler EA, Steinmetz L, Conway A, Wodicka L, et al. A genome-wide transcriptional analysis of the mitotic cell cycle. Mol Cell. 1998;2(1):65-73.

43. Baldi P, Long AD. A Bayesian framework for the analysis of microarray expression data: regularized $t$-test and statistical inferences of gene changes. Bioinformatics. 2001;17(6):509-19.

44. Szallasi Z. Genetic network analysis in light of massively parallel biological data acquisition. Pac Symp Biocomput. 1999:5:16.

45. Friedel CC, Dölken L, Ruzsics Z, Koszinowski UH, Zimmer R. Conserved principles of mammalian transcriptional regulation revealed by RNA half-life. Nucleic Acids Res. 2009;37(17):e115.

46. Hao S, Baltimore D. The stability of mRNA influences the temporal order of the induction of genes encoding inflammatory molecules. Nat Immunol. 2009;10(3):281-8.

47. Legewie $\mathrm{S}$, Herzel $\mathrm{H}$, Westerhoff HV, Blüthgen N. Recurrent design patterns in the feedback regulation of the mammalian signalling network. Mol Syst Biol. 2008:4:190.

48. Hatzimanikatis V, Choe LH, Lee KH. Proteomics: theoretical and experimental considerations. Biotechnol Prog. 1999;15(3):312-8.

49. Chung KY, Agarwal A, Uitto J, Mauviel A. An AP-1 binding sequence is essential for regulation of the human alpha2(I) collagen (COL1A2) promoter activity by transforming growth factor-beta. J Biol Chem. 1996;271(6):3272-8.

50. Ortiz LA, Champion HC, Lasky JA, Gambelli F, Gozal E, Hoyle GW, et al. Enalapril protects mice from pulmonary hypertension by inhibiting TNF-mediated activation of NF-kappaB and AP-1. Am J Physiol Lung Cell Mol Physiol. 2002;282(6):L1209-21.

51. Eferl R, Wagner EF. AP-1: a double-edged sword in tumorigenesis. Nat Rev Cancer. 2003;3(11):859-68.

52. Kim SH, Park HS, Holloway JW, Shin HD, Park CS. Association between a TGFbeta1 promoter polymorphism and rhinosinusitis in aspirin-intolerant asthmatic patients. Respir Med. 2007;101(3):490-5.

53. Tang J, Xiong J, Wu T, Tang Z, Ding G, Zhang C, et al. Aspirin treatment improved mesenchymal stem cell immunomodulatory properties via the 15d-PGJ2/PPARgamma/TGF-beta1 pathway. Stem Cells Dev. 2014;23(17):2093-103.

54. Adiseshaiah P, Vaz M, Machireddy N, Kalvakolanu DV, Reddy SP. A Fra-1dependent, matrix metalloproteinase driven EGFR activation promotes human lung epithelial cell motility and invasion. J Cell Physiol. 2008;216(2):405-12.

55. Tower GB, Coon Cl, Belguise K, Chalbos D, Brinckerhoff CE. Fra-1 targets the AP-1 site/2G single nucleotide polymorphism (ETS site) in the MMP-1 promoter. Eur J Biochem. 2003;270(20):4216-25. 
56. Ho HH, Antoniv TT, Ji JD, Ivashkiv LB. Lipopolysaccharide-induced expression of matrix metalloproteinases in human monocytes is suppressed by IFN-gamma via superinduction of ATF-3 and suppression of AP-1. J Immunol. 2008;181(7):5089-97.

57. Rajasekaran S, Vaz M, Reddy SP. Fra-1/AP-1 transcription factor negatively regulates pulmonary fibrosis in vivo. PLoS ONE. 2012;7(7):e41611.

58. Ma K, Chang D, Gong M, Ding F, Luo A, Tian F, et al. Expression and significance of FRA-1 in non-small-cell lung cancer. Cancer Invest. 2009;27(3):353-9.

59. Takahashi K, Mitsui K, Yamanaka S. Role of ERas in promoting tumour-like properties in mouse embryonic stem cells. Nature. 2003;423(6939):541-5.

60. Aoyama M, Kataoka H, Kubota E, Tada T, Asai K. Resistance to chemotherapeutic agents and promotion of transforming activity mediated by embryonic stem cell-expressed Ras (ERas) signal in neuroblastoma cells. Int J Oncol. 2010;37(4):1011-6.

61. Billington CK, Penn RB. Signaling and regulation of $G$ protein-coupled receptors in airway smooth muscle. Respir Res. 2003;4:2.

62. Gosens R, Schaafsma D, Nelemans SA, Halayko AJ. Rho-kinase as a drug target for the treatment of airway hyperrespon-siveness in asthma. Mini Rev Med Chem. 2006;6(3):339-48.

63. Hirst SJ. Regulation of airway smooth muscle cell immunomodulatory function: role in asthma. Respir Physiol Neurobiol. 2003;137(2-3):309-26.

64. Amano M, Chihara K, Nakamura N, Kaneko T, Matsuura Y, Kaibuchi K. The $\mathrm{COOH}$ terminus of Rho-kinase negatively regulates rho-kinase activity. J Biol Chem. 1999:274(45):32418-24.

65. Araki S, Ito $M$, Kureishi $Y$, Feng J, Machida $H$, Isaka N, et al. Arachidonic acid-induced $\mathrm{Ca} 2+$ sensitization of smooth muscle contraction through activation of Rho-kinase. Pflugers Arch. 2001;441(5):596-603.

66. Taki F, Kume H, Kobayashi T, Ohta H, Aratake H, Shimokata K. Effects of Rho-kinase inactivation on eosinophilia and hyper-reactivity in murine airways by allergen challenges. Clin Exp Allergy. 2007;37(4):599-607.

67. Kelly EA, Jarjour NN. Role of matrix metalloproteinases in asthma. Curr Opin Pulm Med. 2003;9(1):28-33.

68. Demedts IK, Brusselle GG, Bracke KR, Vermaelen KY, Pauwels RA Matrix metalloproteinases in asthma and COPD. Curr Opin Pharmacol. 2005:5(3):257-63.

69. Shibata Y, Kamata T, Kimura M, Yamashita M, Wang CR, Murata K, et al. Ras activation in T cells determines the development of antigen-induced airway hyperresponsiveness and eosinophilic inflammation. J Immunol. 2002;169(4):2134-40.

70. Baker TL, Booden MA, Buss JE. S-Nitrosocysteine increases palmitate turnover on Ha-Ras in NIH 3 T3 cells. J Biol Chem. 2000;275(29):22037-47.

71. Dawson TM, Sasaki M, Gonzalez-Zulueta M, Dawson VL. Regulation of neuronal nitric oxide synthase and identification of novel nitric oxide signaling pathways. Prog Brain Res. 1998;118:3-11.

72. Lander HM, Hajjar DP, Hempstead BL, Mirza UA, Chait BT, Campbell S, et al. A molecular redox switch on p21(ras). Structural basis for the nitric oxide-p21(ras) interaction. J Biol Chem. 1997;272(7):4323-6.

73. Lander HM, Ogiste JS, Pearce SF, Levi R, Novogrodsky A. Nitric oxidestimulated guanine nucleotide exchange on p21ras. J Biol Chem. 1995;270(13):7017-20.

74. Peppelenbosch MP, Qiu RG, de Vries-Smits AM, Tertoolen LG, de Laat SW, McCormick F, et al. Rac mediates growth factor-induced arachidonic acid release. Cell. 1995;81(6):849-56.

75. Woo CH, Lee ZW, Kim BC, Ha KS, Kim JH. Involvement of cytosolic phospholipase A2, and the subsequent release of arachidonic acid, in signalling by rac for the generation of intracellular reactive oxygen species in rat-2 fibroblasts. Biochem J. 2000:348(Pt 3):525-30.

76. Chiarugi P, Pani G, Giannoni E, Taddei L, Colavitti R, Raugei G, et al. Reactive oxygen species as essential mediators of cell adhesion: the oxidative inhibition of a FAK tyrosine phosphatase is required for cell adhesion. J Cell Biol. 2003;161(5):933-44.

77. Pelletier S, Duhamel F, Coulombe P, Popoff MR, Meloche S. Rho family GTPases are required for activation of Jak/STAT signaling by G protein-coupled receptors. Mol Cell Biol. 2003;23(4):1316-33.

78. Taddei ML, Parri M, Mello T, Catalano A, Levine AD, Raugei G, et al. Integrin-mediated cell adhesion and spreading engage different sources of reactive oxygen species. Antioxid Redox Signal. 2007;9(4):469-81.

79. Wu R, Coniglio SJ, Chan A, Symons MH, Steinberg BM. Up-regulation of Rac1 by epidermal growth factor mediates COX-2 expression in recurrent respiratory papillomas. Mol Med. 2007;13(3-4):143-50.
80. Gregg D, de Carvalho DD, Kovacic H. Integrins and coagulation: a role for ROS/redox signaling? Antioxid Redox Signal. 2004;6(4):757-64.

81. Ferro E, Goitre L, Retta SF, Trabalzini L. The Interplay between ROS and Ras GTPases: Physiological and Pathological Implications. J Signal Transduct. 2012;2012:365769.

82. Wells PG, McCallum GP, Chen CS, Henderson JT, Lee CJ, Perstin J, et al. Oxidative stress in developmental origins of disease: teratogenesis, neurodevelopmental deficits, and cancer. Toxicol Sci. 2009;108(1):4-18.

83. Park JS, Heo JS, Chang HS, Choi IS, Kim MK, Lee JU, et al. Association analysis of member RAS oncogene family gene polymorphisms with aspirin intolerance in asthmatic patients. DNA Cell Biol. 2014:33(3):155-61.

84. Wakabayashi Y, Kobayashi M, Akashi-Takamura S, Tanimura N, Konno K, Takahashi K, et al. A protein associated with toll-like receptor 4 (PRAT4A) regulates cell surface expression of TLR4. J Immunol. 2006;177(3):1772-9.

85. Zhang $L, X u A G$, Zhao W, Xu QF, Zhao YM, Li DD, et al. A toll-like receptor 4 (TLR4) variant is associated with asthma severity. Int J Clin Exp Med. 2015:8(5):7849-54

86. Pasare C, Medzhitov R. Toll pathway-dependent blockade of CD4 + CD25+ T cell-mediated suppression by dendritic cells. Science. 2003;299(5609):1033-6.

87. Khatri SB, Holguin FC, Ryan PB, Mannino D, Erzurum SC, Teague WG. Association of ambient ozone exposure with airway inflammation and allergy in adults with asthma. J Asthma. 2009;46(8):777-85.

88. Kurt-Jones EA, Popova L, Kwinn L, Haynes LM, Jones LP, Tripp RA, et al. Pattern recognition receptors TLR4 and CD14 mediate response to respiratory syncytial virus. Nat Immunol. 2000;1(5):398-401.

89. Takahashi K, Shibata T, Akashi-Takamura S, Kiyokawa T, Wakabayashi Y, Tanimura N, et al. A protein associated with Toll-like receptor (TLR) 4 (PRAT4A) is required for TLR-dependent immune responses. J Exp Med. 2007;204(12):2963-76.

90. Szczeklik A. Aspirin-induced asthma as a viral disease. Clin Allergy. 1988; 18(1):15-20.

91. Filipowicz E, Sanak M. Exacerbation of aspirin-induced asthma associated with RSV infection. Przegl Lek. 2003;60(3):185-7.

92. Akira S, Takeda K. Toll-like receptor signalling. Nat Rev Immunol. 2004:4(7):499-511.

93. Steinke JW, Negri J, Liu L, Payne SC, Borish L. Aspirin activation of eosinophils and mast cells: implications in the pathogenesis of aspirin-exacerbated respiratory disease. J Immunol. 2015;193(1):41-7.

\section{Submit your next manuscript to BioMed Central and we will help you at every step:}

- We accept pre-submission inquiries

- Our selector tool helps you to find the most relevant journal

- We provide round the clock customer support

- Convenient online submission

- Thorough peer review

- Inclusion in PubMed and all major indexing services

- Maximum visibility for your research

Submit your manuscript at www.biomedcentral.com/submit 